\title{
Financial Decentralization as a Key Factor in the Socio-Economic Development of Territorial Entities
}

\author{
Volodymyr I. Kravchenko ${ }^{1, *}$, Lina V. Bondareva ${ }^{2}$, Roman Yu. Bykov ${ }^{2}$, Larisa V. Danilova ${ }^{2}$, \\ Olha V. Myrna ${ }^{3}$

\begin{abstract}
${ }^{1}$ Department of Advertising and Public Relations, National Aviation University, Kyiv, 03058, Ukraine ${ }^{2}$ Department of Public Administration and Local Self-Government, Kherson National Technical University, Kherson, 73008, Ukraine ${ }^{3}$ Department of Public Management and Administration, Poltava State Agrarian University, Poltava, 36003, Ukraine
\end{abstract}

Received March 23, 2021; Revised May 30, 2021; Accepted June 15, 2021

\section{Cite This Paper in the following Citation Styles}

(a): [1] Volodymyr I. Kravchenko, Lina V. Bondareva, Roman Yu. Bykov, Larisa V. Danilova, Olha V. Myrna, "Financial Decentralization as a Key Factor in the Socio-Economic Development of Territorial Entities," Universal Journal of Accounting and Finance, Vol. 9, No. 3, pp. 477 - 486, 2021. DOI: 10.13189/ujaf.2021.090322.

(b): Volodymyr I. Kravchenko, Lina V. Bondareva, Roman Yu. Bykov, Larisa V. Danilova, Olha V. Myrna (2021). Financial Decentralization as a Key Factor in the Socio-Economic Development of Territorial Entities. Universal Journal of Accounting and Finance, 9(3), 477 - 486. DOI: 10.13189/ujaf.2021.090322.

Copyright $\mathrm{C} 2021$ by authors, all rights reserved. Authors agree that this article remains permanently open access under the terms of the Creative Commons Attribution License 4.0 International License

\begin{abstract}
The article is devoted to the current problem of introduction and effective functioning of the process of financial decentralization as a key factor in the socio-economic development of territorial entities. It has been found that the problem of creating and implementing effective mechanisms for solving the problem of financial differentiation is one of the most important areas of building effective social and economic policies in the context of the spread of innovative forms of public administration at the local level. There are generalized scientific works on the socio-economic development of territorial entities of Ukraine, given an author's interpretation of this concept in the article. Approaches to the definition of financial decentralization have been systematized and a clarified definition has been provided. The general directions of the introduction and functioning of the institute of financial decentralization are justified. The advantages and disadvantages of the financial decentralization process are identified both for the state as a whole and for a separate territorial entity. A universal system for the functioning of the financial decentralization process has been established, which consists of interconnected subsystems that function on the basis of sustainability and feedback. Quantitative analyses have been performed by the means of constructing an integral indicator. Proposals on directions of improvement of financial decentralization process in modern conditions of Ukraine are presented. It was concluded that the
\end{abstract}

improvement subsystem is a key factor in the success of the entire financial decentralization system by providing continuous feedback for other subsystems for the continuous introduction of new ideas, technologies, and models for managing this process.

Keywords Quality Conditions, Territorial Community, System, Tax Base, Public Administration

\section{Introduction}

In the current context of global processes, the importance of the socio-economic development of individual territorial entities, each of which has unique industrial, agrarian, socio-social, and financial and investment conditions of its existence and opportunities for further development, is significantly strengthened. According to Ye. Yu. Kuzkin, these conditions are determining when searching for and using a set of tools and incentives, by means of which the corresponding part of the authority is transferred to the local authorities, and, consequently, public administration is implemented by bringing administrative and socio-economic services closer to all members of the community, which enhances the ability of territorial communities to solve local 
problems on their own [1]. Thus, in order to solve this problem successfully, regional and local authorities must become key capable organizational and managerial links for the socio-economic development of the territories [2].

The relevance of solving the problem of financial decentralization in Ukraine is also exacerbated by the presence of significant spatial differentiation of the socio-economic development of territorial entities, which is one of the main problems of creating and functioning a competitive market economy of the state and its integration into European and international markets [3]. On the other hand, the differentiation of territorial entities of Ukraine is also characterized by an increase in negative trends in the development of territorial communities due to the inadequate delineation of organizational and managerial powers, the ineffective distribution and redistribution of income and expenses between the state and individual territorial entity [4]. The problem of creating and implementing effective mechanisms for solving the problem of financial differentiation is one of the most important areas of building effective socio-economic policies in the context of the spread of innovative forms of public administration at the local level $[5]$.

The purpose of the article is to study the theoretical and methodological foundations of the introduction and functioning of the financial decentralization process as a key factor in the socio-economic development of territorial entities based on the data obtained from government decentralization reform report and other sources. To achieve the purpose of the study, the following tasks were set:

1. to generalize approaches to the definition of the concepts of "socio-economic development" and "financial decentralization" and make author's definitions of these categories

2. to systematize the overall implementation and operation directions of the financial decentralization institute;

3. to establish a universal system for the functioning of the financial decentralization process;

4. to analyze available information for further consolidation of the theoretical methods.

5. to justify proposals and directions for improving the process of financial decentralization in the modern conditions of Ukraine.

Research on the implementation and functioning of the financial decentralization process in recent years has been a central place in the scientific works of domestic and foreign researchers in the field of local self-government, such as Ye.Yu. Kuzkin [1;2]; O.M. Nepomnyashchyy et al. [3; 4]; T.O. Savostenko and O.Yu. Matviieva [5]; A.P. Lelechenko, O.A. Diegtiar, O.Y. Lebedinska, T.M. Derun and O.V. Berdanova [6]; N.S. Orlova, O.A. Diegtiar, O.V. Kozureva, A.M. Shapovalova and S.I. Prykazka [7]; L.V. Sukharska [8]; Yu.O. Nabatova and T.V. Us [9]; Yu.V.
Kovbasiuk [10]; S.M. Serohin and N.T. Honcharuk [11], S. Picciotto [12]; L.Ye. Simkiv andT. P. Kulyk [13]; Ye.O. Romanenko [14]; A.Yu. Gevorkyan, E.S. Drugova and S.V. Klepikova [15]; N.B. Tataryn and V.V. Voitovych [16]; N.E. Avanesova, O.S. Mordovtsev and Yu.I. Serhiienko [17] and others. But, despite the achievement of significant scientific results in the theoretical and methodological support for the process of financial decentralization of territorial communities, as well as mechanisms for introducing this process into their practical activities, by these scientists, the issues of creating a universal system of directions for the constant improvement of this system remain unresolved.

\section{Materials and Methods}

According to the scientific work on the socio-economic development of the territorial entities of Ukraine $[3 ; 5 ; 6$; $8]$, it can be concluded that in the article this category will be considered as a gradual process, which is one of the key national priorities of the state, which ensures the growth of local income, the creation of quality conditions for the existence of all members of the community through the provision of material resources and public goods. As L.V. Sukharska notes, the process of socio-economic development should be based on the effective and efficient use of the tools of the state's fiscal and tax policies, promote the development and support of social production in accordance with the needs and goals of members of the territorial community [8]. However, it should be noted that these instruments are often insufficient due to spatial territorial differences $[18 ; 19]$. Thus, for the formation of effective mechanisms for the socio-economic development of territorial entities, it is appropriate to determine the definition and study the characteristic features of the concept of "financial decentralization," which is an important step of local budgets in the direction of independence from the state in the fulfilling functions and powers at the territorial level [20;21;22]. Thus, Figure 1 summarizes the scientific works and studies, from which main approaches to the definition of the category "financial decentralization" are highlighted, as well as features of the use of this concept in the realities of Ukraine [23]. Figure 1 shows that financial decentralization is a normative and scientific-based process of distributing functional powers, financial resources and responsibility for their use between the central and local levels of government, which contributes to the growth of the resource base of local budgets, ensuring a transparent and fair redistribution of taxes, which were gathered from the territorial entity and the ability to meet the financial economic and social needs of all members of the territorial community in the changing conditions of the crisis present [24; 25].

It should be noted that financial decentralization is a 
complex process of stimulating the socio-economic development of territorial entity, which is introduced and works in the following directions, as shown in Figure 2. Thus, it can be concluded that the main advantages of financial decentralization are the possibility of horizontal and vertical budgetary competition, which will contribute to the continuous and effective socio-economic development of territorial entities and improve the quality of public services provided by local authorities, focusing on the individual characteristics and preferences of members of the territorial community $[26 ; 27 ; 28]$. On the other hand, financial decentralization can be a factor in the emergence of a number of economic, political and social risks, which are manifested in the emergence of corruption at the local level, a decrease in state influence on the development of territorial entities, an increase in the already significant spatial socio-economic differentiation of communities and an increase in separatist sentiment.

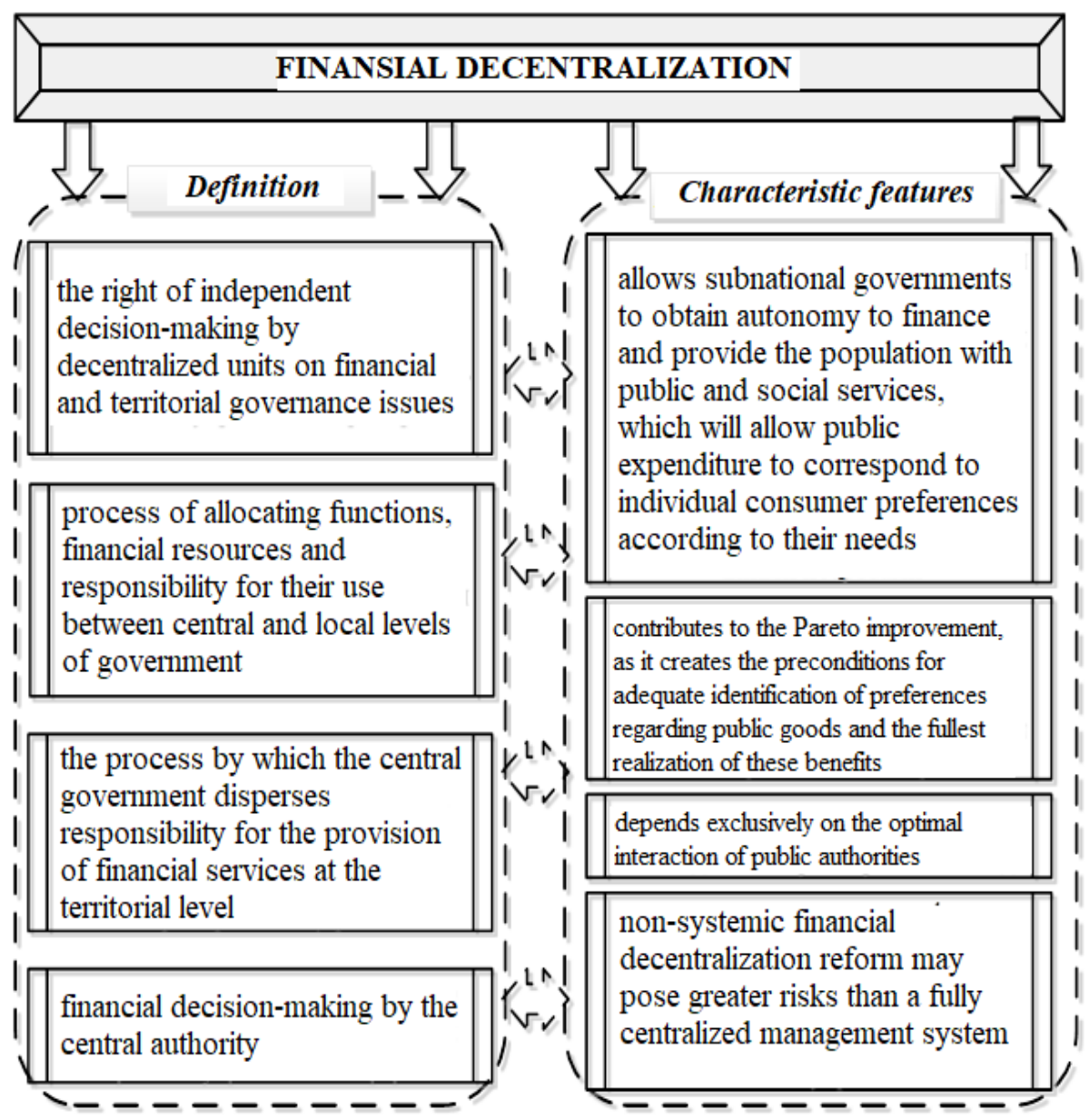

Figure 1. Systematization of approaches to the definition of the concept of "financial decentralization" $[2 ; 9-13 ; 29 ; 30]$ 


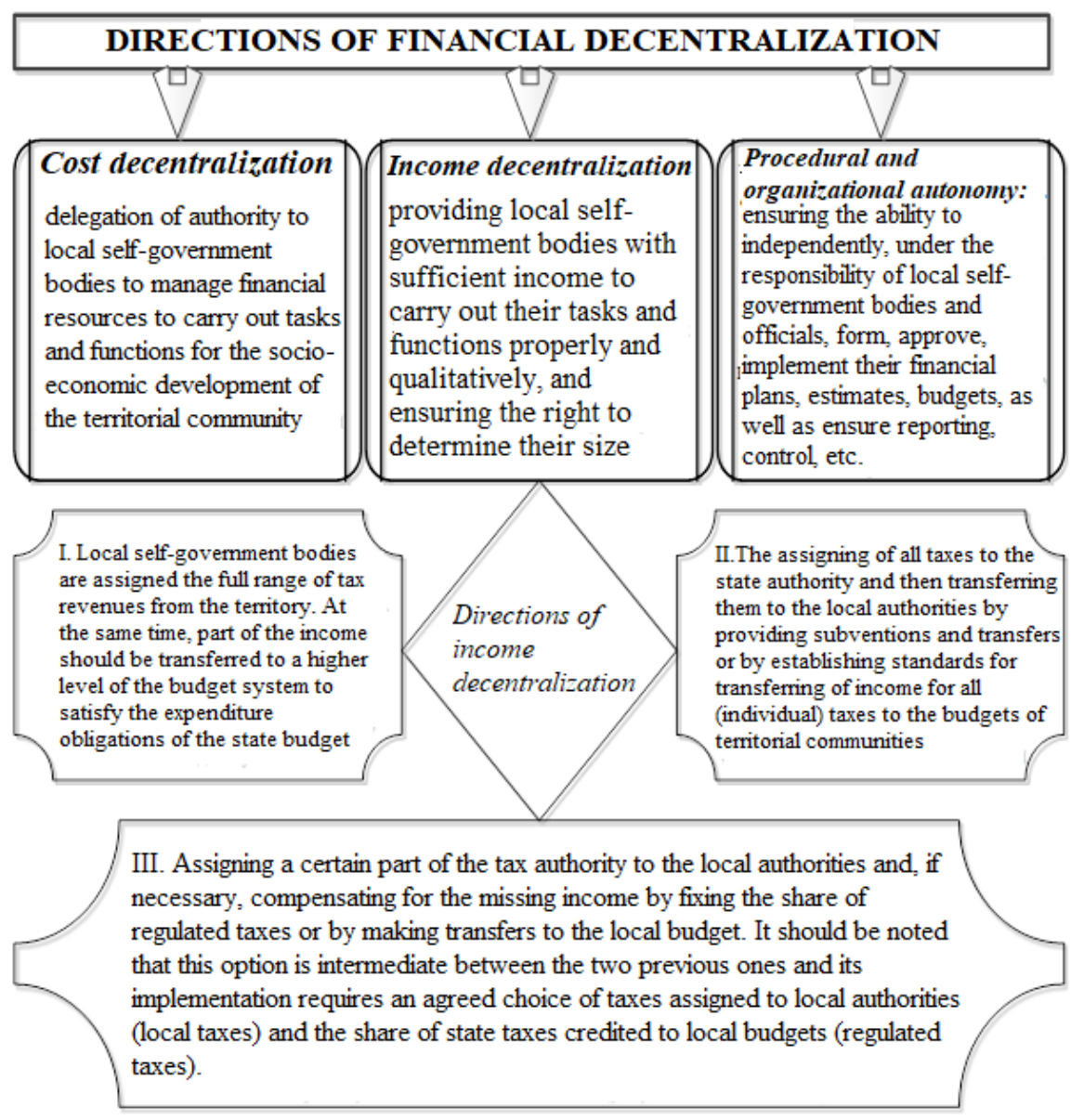

Figure 2. General directions of implementation and functioning of financial decentralization institute

\section{Results and Discussion}

In order to smooth out these destructive factors of the impact on the success of the implementation and functioning of the financial decentralization process and the increase in the efficiency of using all the advantages of this process, there is an urgent need to systematize the theoretical and methodological foundations and practical measures with comparative official data for the implementation and improvement of certain theoretical components [31; 32]. It is known that in 2015-2019, 4.330 Ukrainian communes amalgamated or started the process of financial decentralization [33].

Table 1. Number of amalgamated communes

\begin{tabular}{|c|c|}
\hline Year & Number of communes \\
\hline 2016 & 1782 \\
\hline 2017 & 3178 \\
\hline 2018 & 3740 \\
\hline 2019 & 4330 \\
\hline
\end{tabular}

This number of communes corresponds to $39.5 \%$ of the total number of local councils as of 1 January, 2015, and $33 \%$ of the territory of Ukraine [34]. As a result of the reform, Ukraine has become one of the most decentralized countries in Europe. Local government revenues increased from 441 billion UAH to 569 billion UAH, which is increase 29 after adjustment of inflation. They increased both as a share of GDP (from $14 \%$ to $16 \%$ ) and as a share of total government revenues (from $34 \%$ to $41 \%$ ). Revenues of local communities also increased by $39 \%$ (from 42 billion UAH to 69 billion UAH), and there is some evidence that at least some local governments are making greater efforts to generate their own revenues [34].

With this data, model for assessing the budgetary system can be generalized to study the state of financial decentralization in Ukraine. The method of constructing an integral indicator was chosen. Firstly, indicators of financial decentralization must be selected: share of local budget income in GDP; share of local budget expenditures in GDP; share of local budget income in consolidated budget of Ukraine (CBU) income; share of local budget expenditures in $\mathrm{CBU}$ expenditures; financial decentralization coefficient by consolidated budget expenditures; share of transfers in total income of local budget; share of transfers in total expenditure of local budgets; ratio of transfers to local budgets from the state one, in \% to GDP; share of tax revenues in total income of local budgets; ratio of tax burden to GDP; share of 
non-tax revenues in total income of local budget, etc. Secondly, the differentiation of indicators into incentives and disincentives (1).

$$
a_{i j}^{S}=\frac{x_{i j}}{\max \left\{x_{i j}\right\}} ; a_{i j}^{d}=\frac{\min \left\{x_{i j}\right\}}{x_{i j}}
$$

Where $a_{i j}^{5} ; a_{i j}^{d}-$ normalized values of range for incentives and disincentives; $x_{i j}$ - current value of range; $\max \left\{x_{i j}\right\}-$ maximum value of range; $\min \left\{x_{i j}\right\}-$ minimum value of range.

Thirdly, the calculation of an integral indicator of financial decentralization (2).

$$
\text { Dyi }=\sqrt[n]{a_{1 j}^{S / d} * a_{2 j}^{S / d} * \ldots * a_{n j}^{S / d}}
$$

Where Dyi - the integral indicator of financial decentralization; $a_{1 j}^{S / d} \ldots a_{n j}^{S / d}-$ normalized values of indicators; $\mathrm{n}$ - the number of indicators.

According to methodology above, indicators of financial decentralization were calculated and combined with data from official sources indicators of financial decentralization in Ukraine for 2015-2019.

\begin{tabular}{|c|c|c|c|c|c|}
\hline \multirow{2}{*}{ No } & \multirow{2}{*}{ Indicator } & \multicolumn{4}{|c|}{ Year } \\
\hline & & 2016 & 2017 & 2018 & 2019 \\
\hline 1 & Share of local budgets income in GDP, $\%$ & 14.783 & 14.876 & 15.365 & 16.838 \\
\hline 2 & Share of local budget expenditures in GDP, $\%$ & 14.404 & 14.153 & 14.704 & 16.636 \\
\hline 3 & Share of local budget income in CBU income, $\%$ & 22.154 & 18.482 & 21.810 & 22.567 \\
\hline 4 & Share of local budget expenditures in CBU expenses, $\%$ & 42.733 & 40.737 & 41.936 & 46.370 \\
\hline 5 & Financial decentralization coefficient by consolidated budget expenditures & 0.490 & 0.425 & 0.448 & 0.482 \\
\hline 6 & Share of transfers in local budgets income, $\%$ & 56.390 & 58.798 & 53.366 & 54.293 \\
\hline 7 & Share of transfers to local budgets expenditures, $\%$ & 0.965 & 1.123 & 4.491 & 1.203 \\
\hline 8 & Ratio of transfers to local budgets from the state one, in $\%$ to GDP & 8.475 & 8.906 & 8.860 & 9.342 \\
\hline 9 & Share of tax revenues in total income of local budgets, $\%$ & 37.709 & 33.362 & 40.121 & 40.033 \\
\hline 10 & Tax burden to GDP ratio, $\%$ & 23.458 & 25.651 & 27.309 & 27.772 \\
\hline 11 & Share of non-tax revenues in total income of local budgets, $\%$ & 5.292 & 6.843 & 5.970 & 5.173 \\
\hline 12 & Level of plan fulfillment for local budgets income, $\%$ & 91.5 & 103.5 & 104.2 & 100.7 \\
\hline 13 & Level of plan fulfillment for local budget, expenditures, $\%$ & 84.545 & 93.859 & 93.189 & 92.823 \\
\hline 14 & Coefficient of income autonomy & 0.436 & 0.409 & 0.466 & 0.457 \\
\hline 15 & Autonomy coefficient for local budget expenditures & 0.448 & 0.430 & 0.487 & 0.463 \\
\hline 16 & Tax potential coefficient & 0.238 & 0.193 & 0.226 & 0.243 \\
\hline 17 & Tax efforts coefficient for local bodies & 0.222 & 0.185 & 0.218 & 0.226 \\
\hline
\end{tabular}

Table 1. Indicators of financial decentralization in Ukraine for 2016-2019 


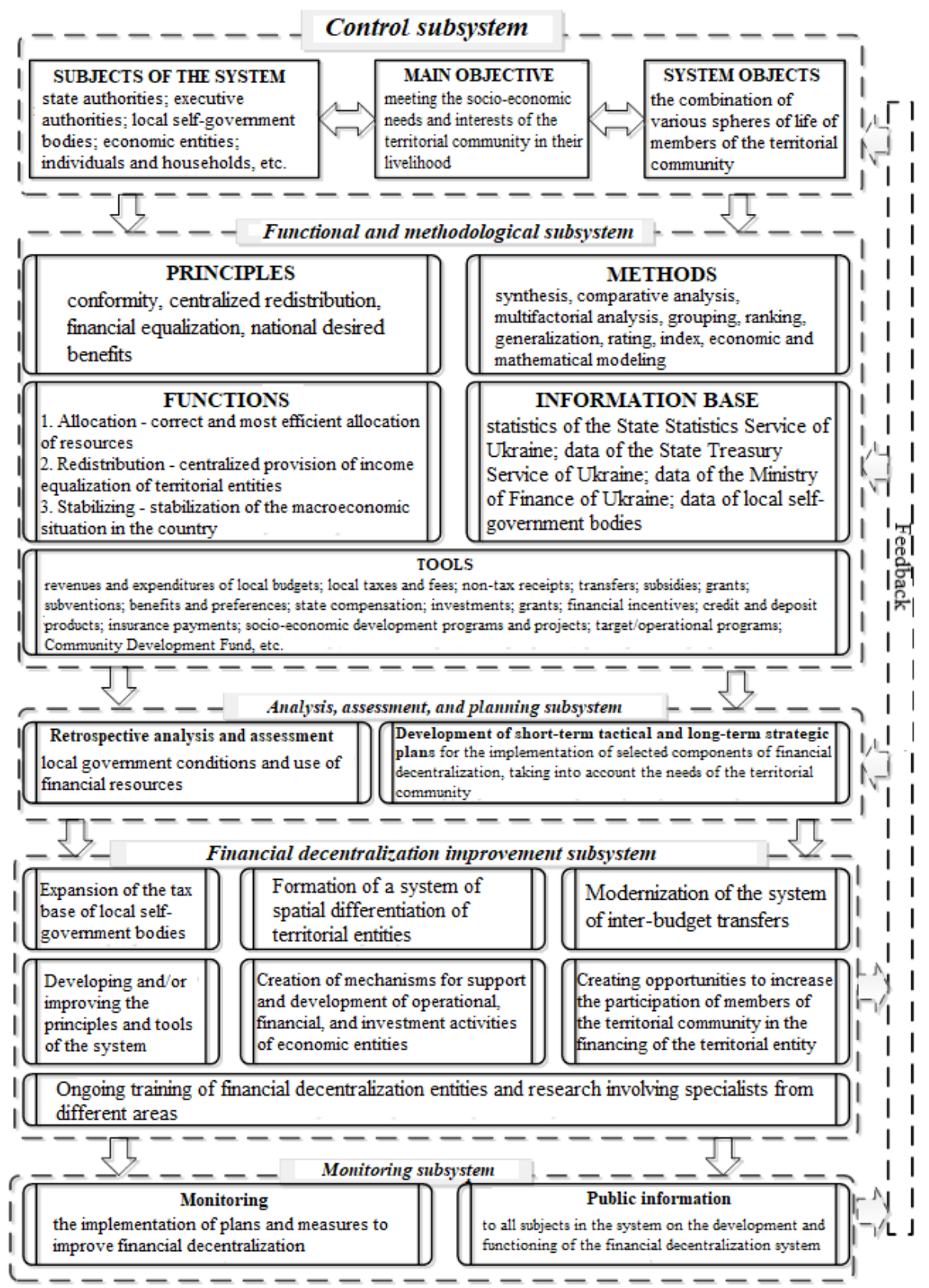

Figure 3. Financial decentralization functioning system $[4 ; 7 ; 14 ; 33]$

Obtained results indicate that inter-government transfers a significant factor influencing the level of financial decentralization of local budgets which confirms the correctness of chosen functioning system.

So, in Figure 3, we will form a universal model of the system of functioning of the financial decentralization process, which includes a set of specified subsystems, namely:

1. a control subsystem that includes entities and objects associated with the target;

2. a functional and methodological subsystem consisting of certain methods, principles, functions, and a tool-information base, which, in fact, form the basis of the entire system;
3. analysis, assessment and planning subsystem, which allows, on the basis of analysis and assessment of retrospective information, it possible to form effective and transparent plans for the introduction of new components into the financial decentralization system, as well as improving existing ones;

4. a subsystem for improving the financial decentralization system, which contains the measures proposed by the authors to create improved working conditions for the entire system;

5. control subsystem - is a key feedback subsystem between entities of the financial decentralization system for monitoring the success or failure of this process. 
The main feature of the system developed in Figure 2 is the allocation of seven areas in the subsystem for improving the process of financial decentralization, which should become the key to the constant socio-economic development of territorial entities in modern crisis conditions [35].

1. Expansion of the tax base of local self-government bodies.

As the experience and practical results of studies show [15], the vast majority of territorial communities (including the amalgamated territorial communities) do not have the opportunity to fully meet the need for the necessary budgetary resources for various purposes through fiscal contributions, which are the main source of income of local budgets [36;37]. Thus, increasing the importance of local taxes and fees and increasing their share is now one of the main tasks at both the state and local levels [38]. To address the issue, the study proposes the following activities:

a) to expand the list of local taxes and fees, as well as the powers of local self-government bodies to introduce and collect them, taking into account the real capabilities of territorial communities, the conditions of their existence and the experience gained (including historical ones). At the same time, it should be noted that the general list of taxes established by the legislation of Ukraine should not limit the tax initiative of local authorities [16];

b) to define a list of local taxes and fees that will be mandatory throughout Ukraine, and if it is impossible to collect or not accept such taxes in a separate territorial entity, it is appropriate to grant the right to the relevant authorities to charge them at the minimum possible rates. The minimum and maximum amount of each tax should also be set to allow the differentiation of individual tax rates. The proposed measure will solve the problem of spatial differentiation of territorial entities of Ukraine set in the article [39; 40];

c) to classify certain state taxes as local taxes, which will stimulate an increase in the dynamics of financial and economic turnover by building socio-economic infrastructure in certain territorial entities;

d) to eliminate "inefficient" taxes, which had more costs for their administration than revenues.

2. Establishment and/or improvement of principles and tools for the functioning of the financial decentralization process.

The principles and tools highlighted in Figure 3 are primarily for public use. Therefore, each territorial community can form and apply its own principles and tools, which must provide for organizational and managerial documents, namely, statutes, strategies, programs, projects, scientific research, etc. Thus, there is flexibility in making effective decisions aimed at achieving better results in the existing operating environment, using the potential of the territorial entity [41;42].

3. Formation of a system for balancing spatial differentiation of territorial entities.

The problem of spatial differentiation generates two negative trends, namely:

a) financially weak (depressed) territorial communities are usually not interested in independently increasing their financial potential to a certain level, due to the non-receiving of basic and additional subsidies from the state budget in full in the future;

b) territorial entities with high financial potential also do not seek to improve significantly their financial results, due to the withdrawal of funds in the form of a reverse donation in favor of financially weak territorial communities.

To solve this problem, it is appropriate to offer an opportunity to expand its own tax base depending on the performance of territorial communities. Thus, both the activities of the individual territorial community and their inaction will be taken into account and, accordingly, relevant preferences will be given or state support will be reduced.

4. Creation of mechanisms for supporting and developing operational, financial and investment activities of economic entities.

It should be noted that due to the efficiency and especially the performance of the functioning of large, medium and small businesses, the income of local budgets of territorial entities is increased.

The creation of an investment climate for territorial entity deserves special attention in this direction and includes the following activities:

a) the introduction of a modern information system on the investment capacity of society through the use of both traditional sources of its dissemination and modern innovative technologies in this area;

b) the simplification of procedures for seeking and servicing investors by local authorities;

c) the establishment of preferential tax and other conditions for new and/or permanent investors for a certain period of time;

d) creating opportunities for local authorities to conduct their commercial activities in a transparent and stable manner [17].

5. Modernization of the system of inter-budget transfers.

As a result of the studies carried out to improve the system of inter-budget relations in Ukraine, the following measures were introduced: 
a) the transparent distribution of powers between the center, regional and local self-government bodies in the budgetary relations, which will contribute to the effective interaction of various levels of the budget;

b) the formation and implementation of a mechanism to ensure consistency between the expenditures of the territorial entity budget and the profitable sources necessary for their financing;

c) providing opportunities for the socio-economic growth of territorial communities, which will allow the development of budgetary discipline and allow for effective management decisions;

d) sending the surplus result of local budgets to higher-level budgets, which will contribute to more effective use of available financial resources;

e) regulatory support for the management of inter-budgetary relations, achieving stability and transparency in the formation of budgets at all levels.

6. Creating opportunities to increase the participation of members of the territorial community in the financing of territorial entity.

The essence of this direction of improvement is based on the principles of compliance with the principle of publicity and transparency. This approach will increase the confidence of civil society in the existing local budgetary policy of territorial entity and enhance the effectiveness of public control over the use of local finance, etc.

It should be noted that in the modern conditions of Ukraine, financial control by responsible members of the territorial community is an imperfect and even abstract concept. Therefore, members of the public, first of all, not only need to fulfill their duties, but also to know how to realize their rights and actively participate in solving issues of social and economic development of society.

7. Ongoing training of financial decentralization entities and research involving specialists from different fields.

The implementation of this direction consists in the organization of innovative forms of training of entities responsible for the effective functioning of the financial decentralization system $[43 ; 44]$, with the involvement of leading specialists and scientists in the field, international and foreign organizations to obtain the necessary experience of developed countries, as well as the introduction of certificate training programs together with rating educational institutions of Ukraine and the world.

Thus, the improvement subsystem is a key factor in the success of the entire financial decentralization system by providing feedback for other subsystems for the continuous introduction of new ideas, technologies and models for managing this process.

\section{Conclusions}

Theoretical and methodological aspects and practical directions of improving the financial decentralization process were considered in the article and proved that the effective implementation and functioning of this process is a key factor in the success of the socio-economic development of territorial entity. In the course of the study, the objectives were solved and conclusions were made, namely:

1. The synthesis of scientific works and approaches made it possible to make author's definitions of the following categories:

a) socio-economic development is a gradual process that is one of the key national priorities of the state, which ensures the growth of local incomes, the creation of quality conditions for the existence of all members of the community through the provision of material resources and public goods;

b) financial decentralization is a normative and scientific-based process for the allocation of functional powers, financial resources and responsibility for their use between the central and local levels of government, which contributes to the growth of the resource base of local budgets, ensuring a transparent and fair redistribution of taxes, collected from territorial entity and the possibility of meeting the financial economic and social needs of all members of the territorial community in the changing conditions of the crisis present.

2. The general directions of the introduction and functioning of the institute of financial decentralization are systematized, namely: the decentralization of expenses, the decentralization of income and the intermediate option - procedural and organizational autonomy. It was concluded that the advantages of implementing this process are the possibility of ensuring horizontal and vertical budgetary competition, which will contribute to the continuous and effective socio-economic development of territorial entities and improve the quality of public services provided by local authorities, focusing on the individual characteristics and preferences of members of the territorial community.

3. A universal system for the functioning of the financial decentralization process has been developed, which includes a set of allocated subsystems, namely, the management subsystem; functional and methodological subsystem; analysis, assessment and planning subsystem; a subsystem for improving financial decentralization; and control subsystem.

4. It has been proved that the subsystem for improving the process of financial decentralization should be the key to the constant socio-economic development of territorial entities in modern crisis conditions. The 
article identifies and describes the mechanism for their introduction and implementation of seven main areas of improvement of this process, namely: the expansion of the tax base of local self-government bodies; developing and/or improving the principles and tools of the financial decentralization process; the formation of a system for balancing spatial differentiation of territorial entities; the creation of mechanisms to support and develop operational, financial and investment activities of economic entities; the modernization of the inter-budget transfer system; creating opportunities to increase the participation of members of the territorial community in the financing of territorial entity; continuous training of financial decentralization entities and research involving specialists from different fields.

\section{REFERENCES}

[1] Ye. Yu. Kuzkin. Financial support of local fiscal space self-government, Simon Kuznets Kharkiv National University of Economics, PP "Tekhnolohichnyi Tsentr", Kharkiv, 2019.

[2] Ye.Yu. Kuzkin. Estimation of structural and regional differentiation of municipal budgets under financial decentralization (case for Ukraine), Public and Municipal Finance, Vol. 7, No. 4, 29-40, 2018.

[3] O.M. Nepomnyashchyy, O.A. Marusheva, Yu.H. Prav, O.V. Medvedchuk, I.A. Lahunova. Certain aspects of the system of public administration of universities: world practices and the Ukrainian dimension, Universal Journal of Educational Research, No. 8(11D), 82-86, 2020.

[4] O.M. Nepomnyashchyy, I.M. Shevchenko, O.A. Marusheva, O.V. Medvedchuk, I.A. Lahunova. Marketing communications management in the public administration system, International Journal of Criminology and Sociology, No. 9, 2882-2890, 2020.

[5] T.O. Savostenko, O.Yu. Matveieva. Implementation of the constitutional principles of decentralization public administration by achievement financial autonomy of the territories of Ukraine, Efficacy Public Administration, No. 40, 198-204, 2014.

[6] A.P. Lelechenko, O.A. Diegtiar, O.Y. Lebedinska, T.M. Derun, O.V. Berdanova. Mechanisms of inter-state communications for solving sustainable development problems, Asia Life Sciences, No. 29(2), 1-9, 2020.

[7] N.S. Orlova, O.A. Diegtiar, O.V. Kozureva, A.M. Shapovalova, S.I. Prykazka. Financial capacity of territorial communities: european experience and Ukrainian case, Financial and Credit Activity: Problems of Theory and Practice, No. 4(31), 516-526, 2019.

[8] L.V. Sukharska. Analysis of the state of financial support for the development of united territorial communities in modern Ukraine, Public Administration: Theory and Practic: Electronic Academic Professional Periodical, No. 1, 92-101, 2017.
[9] Yu.O. Nabatova, T.V. Us. Formation of local budgets in the conditions of decentralization of financial resources. Efficient Economy, 5, Online available from: $\mathrm{http} / / / \mathrm{www}$.economy.nayka.com.ua/?op=1\&z=4100, 2015.

[10] Yu.V. Kovbasiuk. New approaches to regional policy formation and regional governance, Actual Problems of Economics, No. 7(157), 246-253, 2014.

[11] S.M. Serohin, N.T. Honcharuk. Theoretical principles and main directions of local government reform and decentralization of power in Ukraine, Public Administration Aspects, No. 4, 111-120, 2015.

[12] S. Picciotto. Regulation: managing the antinomies of economic vice and virtue, Social and Legal Studies, No. 26(6), 676-699, 2017.

[13] L.Ye. Simkiv, T.P. Kulyk. Local government reform in Ukraine: trends and problem aspects, Scientific Bulletin of the International Humanities University, No. 28, 15-18, 2017.

[14] Ye.O. Romanenko. Place and role of communication in public policy, Actual Problems of Economics, No. 2(176), 25-31, 2016.

[15] A.Yu. Gevorkyan, E.S. Drugova, S.V. Klepikova. Factors affecting the definition of investment attractiveness and business value, Bulletin of the National Technical University "Kharkiv Polytechnic Institute", No. 19(1295), 131-134, 2018.

[16] N.B. Tataryn, V.V. Voitovych. Local budgets as financial basis of local self-government, Scientific Bulletin of Uzhhorod National University, No. 11, 159-162, 2017.

[17] N.E. Avanesova, O.S. Mordovtsev, Yu.I. Serhiienko. Theoretical and methodological bases of identification and interrelation of influence of destabilizing factors on economic safety of the industrial enterprise, Business Inform, No. 9, 20-28, 2020.

[18] A. Lapidus, A. Khubaev, T. Bidov. Development of a three-tier system of parameters in the formation of the organizational and technological potential of using non-destructive testing methods, E3S Web of Conferences, No. 97, 06037, 2019.

[19] A. Tkachenko. The importance of the ILO in international processes the centenary of the international organization, Mezhdunarodnye Protsessy, No. 17(3), 36-50, 2019.

[20] D. Madiyarova, A. Amirbekova, M. Syrlybayev. Comparative advantages of Kazakhstan assessed by the Balassa Index: Consistently competitive exports are limited to raw materials with low added value, Journal of Business and Retail Management Research, No. 12(3), 201-210, 2018.

[21] L.G. Polyakova, V.A. Ageeva, L.L. Balaniuk. The evolution of public views of the Black Sea province during the First World War, Bylye Gody, No. 38(4), 1093-1104, 2015.

[22] D. Madiyarova, R. Abdrakhmanova. Socioeconomic effects of integration actions (the study case of the customs union), Actual Problems of Economics, No. 135(9), 393-401, 2012.

[23] I.O. Bashynska. Using SMM by industrial enterprises, 
Actual Problems of Economics, No. 12(186), 360-336, 2016.

[24] L. Obolenskaya, E. Moreva, T. Sakulyeva, V. Druzyanova. Traffic forecast based on statistical data for public transport optimization in real time, International Review of Automatic Control, No. 13(6), 264-272, 2020.

[25] S. Zhang, T. Sakulyeva, E. Pitukhin, S. Doguchaeva. Neuro-fuzzy and soft computing - A computational approach to learning and artificial intelligence, International Review of Automatic Control, No. 13(4), 191-199, 2020.

[26] A. A. Kartskhiya, S. A. Tyrtychnyy, M. G. Smirnov, M. G. Dolgikh, L. A. Khmelnitskiy. Digital technologies in supply chain management for production and digital economy development, International Journal of Supply Chain Management, No. 9(3), 912-918, 2020.

[27] O. Sivash, D. Ushakov, M. Ermilova. Investment process resource provision in the agricultural sector, IOP Conference Series: Earth and Environmental Science, No. 272(3), 032118, 2019.

[28] L.M. Yemelianenko, V.L. Osetskyi, D.V. Osetska. Institutional imperatives of the expansion of the fiscal space of Ukraine in the process of european integration, Scientific Bulletin of Polissia, No. 4(12), 72-78, 2017.

[29] Yu.O. Radelytskyi. Problems of local budgets' organization in Ukraine in the context of financial decentralization, The World of Finance, No. 2(51), 29-41, 2017.

[30] T. Sakulyeva. Towards the development of innovative technologies for the "mobility as a Service" system. Journal of Physics: Conference Series, No. 1515(3), 032003, 2020.

[31] V.Y. Bocheliuk, N.Y. Zavatska, Y.O. Bokhonkova, M.V. Toba, N.S. Panov. Emotional burnout: Prevalence rate and symptoms in different socio-professional groups, Journal of Intellectual Disability - Diagnosis and Treatment, No. 8(1), 33-40, 2020.

[32] V.Y. Bocheliuk, S.F. Denysov, T.A. Denysova, V.M. Palchenkova, N.S. Panov. Psychological and legal problems for ensuring human rights, Rivista di Studi sulla Sostenibilita, No. 2020(1), 235-245, 2020.

[33] Monitoring of the power decentralization process and local self-government reform, Online available from: https://storage.decentralization.gov.ua/uploads/library/file/ 465/10.08.2019_ENG.pdf

[34] Reform for subnational and finance of local government bodies in Ukraine: 2014-2018, Online available from: http://sklinternational.org.ua/wp-content/uploads/2019/11/ PolicyBrief-UKR-FINAL.pdf

[35] T. Canare, J.P. Francisco, R.A.C. Caliso. Decentralization and income inequality in a panel and cross-section of countries, Journal of International Development Volume, No. 32(4), 543-579, 2020.

[36] V.N. Zavadskyi, O.S. Aleksandrova, N.N. Vinnikova, O.S. Vyhovska, I.N. Spudka. European Union enlargement in 2004: system analysis of the benefits and losses, Journal of Advanced Research in Law and Economics, No. 10(6), 1714-1722, 2019.

[37] O.S. Aleksandrova, V.V. Loiko, N.M. Vinnikova. Trade in the Decade Following the Collapse of the USSR, Visual Anthropology, No. 33(2), 128-137, 2020.

[38] T.V. Yereskova, O.V. Mazuryk, O.S. Aleksandrova, H.V. Tymofieieva, V.N. Zavadskyi. Uncertainty as a regular feature of modern Ukrainian society, Teorija in Praksa, No. 57(3), 928-946, 2020.

[39] D. Ushakov, M. Ermilova. Autoregulators in the housing market financing system: A structurally functional approach, E3S Web of Conferences, No. 164, 09003, 2020.

[40] E. Shavina, V. Prokofev. The cluster approach in the economic and innovative development of mining region (on the example of the Kemerovo region), E3S Web of Conferences, No. 174, 04017, 2020.

[41] T.N. Lebedyuk. Information technology development trends in the Russian Federation and Europe and their impact on the competitiveness of countries, Information Age, No. 5(4), 1-10, 2021.

[42] N. Israfilov, I. Ablaev, A. Seisinbinova, T. Sakulyeva. Impact of supply chain management strategies on the performance indicators of small and medium-sized businesses, International Journal of Supply Chain Management, No. 9(4), 544-552, 2020.

[43] V. Rysin, O. Galenko, N. Duchynska, N. Kara, O. Voitenko, A. Shalapak. Financial convergence as a mechanism for modifying sectors of the global financial services market, Universal Journal of Accounting and Finance, Vol. 9, No. 1, 65-73, 2021. DOI: 10.13189/ujaf.2021.090107

[44] N. Abdullah, A. Roslan, R.Y.M. Yusuf, M.F.R.M. Rasid. Behavior of Malaysian iGeneration in purchasing life insurance policy, Universal Journal of Accounting and Finance, Vol. 8, No. 4, 153-160, 2020. DOI: 10.13189/ujaf.2020.080408 